\section{Mineralogy and Crystal Structure of Greenalite}

Greenalite, a hydrous ferrous silicate, was first described in detail by Leith ${ }^{1}$; heavy contamination by other constituents of the iron-ore in which it occurred made analysis difficult. Discrepancies between analyses of the mineral by Leith and by Jolliffe ${ }^{2}$ were ascribed by Gruner ${ }^{3}$ to different methods of correcting for insoluble silica. Gruner found the $X$-ray pattern to be very similar to that of chrysotile, but different from chlorite, micas and chamosite. Gruner ascribed to greenalite a unit cell similar to chrysotile, although he found it impossible to tell whether the $\beta$-angle differed from that of chrysotile, $93^{\circ} 16^{\prime}$. Gruner's analysis corresponded to a structural formula of $\mathrm{Fe}^{2}{ }_{4 \cdot 8} \mathrm{Fe}^{3}+{ }_{1 \cdot 0}\left(\mathrm{Si}_{4} \mathrm{O}_{10}\right)(\mathrm{OH})_{8}$.

Recent research ${ }^{4}$ on chamosite from sedimentary ironstones, also a hydrous ferrous silicate, has shown it to be member of the krolin-antigorite group with an orthohexagonal unit cell, and layers stacked in an orthohexagonal, monoclinic or disordered sequence ${ }^{5}$. Since greenalite and chamosite were similar in composition, Gruner's finding that their X-ray patterns differed was unexpected, and a re-examination of greenalite was made with a Brindley powder camera. The greenalite diagram closely resembled chamosite, much more so than chrysotile. Contaminants gave sharp lines, while the greenalite gave broader lines which were due to the principal orthohexagonal indices. In particular, the clarity of the $20 l$ series showed that, unlike many chamosites ${ }^{6}$, greenalite has little or no $a$-disorder. No monoclinic form was observed.

In comparing cell dimensions, the $a_{0}$ and $c_{0}$ values for chrysotile have been transposed, but the double $b_{0}$ and $c_{0}$ dimensions have not been altered (Table 1 ).

Table 1

\begin{tabular}{|c|c|c|c|c|c|}
\hline & $\begin{array}{c}\text { Chrysotile } \\
\text { (Gruner) }\end{array}$ & $\begin{array}{l}\text { Greenalite } \\
\text { (Gruner) }\end{array}$ & $\begin{array}{l}\text { Greenalite } \\
\text { (present } \\
\text { work) }\end{array}$ & $\begin{array}{l}\text { Lateritic } \\
\text { chamosite } \\
\text { (Brindley) }\end{array}$ & $\begin{array}{l}\text { Ironstone } \\
\text { chamosite } \\
\text { (Brindley } \\
\text { and Youell) }\end{array}$ \\
\hline $\begin{array}{l}a_{0} \\
b_{0} \\
c_{0} \\
\beta\end{array}$ & $\begin{array}{l}5 \cdot 32 \\
18 \cdot 6 \\
14 \cdot 5 \\
93^{\circ} 16^{\prime}\end{array}$ & $\begin{array}{l}5 \cdot 32 \\
18 \cdot 6 \\
14 \cdot 5 \\
? 93^{\circ} 16^{\prime}\end{array}$ & $\begin{array}{l}5 \cdot 54 \\
9 \cdot 59 \\
7 \cdot 19 \\
90^{\circ}\end{array}$ & $\begin{array}{l}5 \cdot 38 \\
9 \cdot 31 \\
7 \cdot 03 \\
90^{\circ}\end{array}$ & $\begin{array}{c}5 \cdot 40 \mathrm{kX} . \\
9 \cdot 36 \mathrm{kX} . \\
7 \cdot 10 \mathrm{kX} . \\
90^{\circ}\end{array}$ \\
\hline
\end{tabular}

The hydrous ferrous silicates vary considerably in chemical composition, giving rise to differences in unit cell dimensions even among specimens of the same mineral. Two factors are important in comparing the unit cells of greenalite and chamosite. Greenalite has very little replacement of tetrahedral $\mathrm{Si}$ by $\mathrm{Al}$, compared with chamosite. This factor by itself would produce a reduction of $a_{0}$ and $b_{0}$ by the same fraction, and a $c_{0}$ increase of about twice this fraction. The octahedral sites in the greenalite structure are nearly all filled by the large ferrous ion, whereas in chamosite appreciable substitution by the smaller $\mathrm{Al}$ ion occurs. Greenalite would be expected to have larger values of $a_{0}, b_{0}$ and $c_{0}$ due to this factor, with the effect about four times as great for $a_{0}$ and $b_{0}$ as for $c_{0}$. Combination of these two factors in greenalite produces a structure in which all parameters are greater than in chamosite, the increase being 3 per cent for $a_{0}$ and $b_{0}$ and $2 \cdot 3$ per cent for $c_{0}$.

Greenalite oxidizes and becomes dehydrated to a high-temperature ferric form, but this is nct so well defined as in chamosite. The oxidized and sometimes partially leached form of chamosite occurs extensively in weathered sedimentary ironstones. It seems likely that a similar phenomenon occurs with greenalite in the field, giving rise to Jolliffe's 'Mineral X'. Despite the similarity of the two minerals, greenalite is virtually free from alumina, whereas in most chamosites, the ratio $\mathrm{Al} / \mathrm{Si}$ is very nearly 1 . In view of the differences in environment and deposition of greenalite and chamosite, resemblance in all respects would not be expected. In both cases, however, the low iron content of the hydrous silicates relative to iron oxides and siderite, and the high silica content, render rocks containing a high proportion of these minerals unworkable as iron ores, and intractable to beneficiation processes based on physical methods.

A full account of this work will be published later.

Department of Physics,

R. Steadman

Huddersfield Tochnical College,

X-Ray Laboratories,

Department of Physics, University of Leods.

${ }^{1}$ Leith, C. K., U.S. Geol. Survey, Mon. 43, 101 (1903).

2 Jolliffe, F., Amer. Min., 20, 405 (1935).

${ }^{3}$ Gruner, J. W., Amer. Min., 21, 449 (1936).

- Brindley, G. W., Min. Mag., 29, 502 (1951).

${ }^{5}$ Brindley, G. W., and Youell, R. F., Min. Mag., 30, 57 (1953).

'Youell, R. F., Nature, 176, 560 (1955).

\section{Rapid Sedimentation of Proteins through Starch}

PACKed potato starch, which has been widely used for zone electrophoresis, offers certain advantages when employed as a supporting medium in the ultracentrifuge. Boundaries are stabilized, making recovery of fractions easier, and the proteins thus far studied sediment at least twice as rapidly in starch as in free solution. This has been shown in experiments with rat hæmoglobin (1 per cent) or bovine serum albumin (1-5 per cent) stained with bromphenol blue centrifuged in starch and in free solution under identical conditions. Centrifugation was done in the 'Spinco' Model $L$ centrifuge by use of an $S W 391$ swinging-bucket rotor at approximately $20^{\circ}$. A 0.1 ionic strength $p H \mathbf{H} \cdot 5$ phosphate-sodium chloride buffer was used in each instance. The 'Lusteroid' centrifuge tubes were completely filled with a slurry of starch-protein mixture and accelerated briefly to 20,000 r.p.m. After deceleration, excess fluid was removed and more starch slurry added. The packing procedure was repeated a second time and excess fluid again removed. It is important that the starch suspensions be freshly made, since part of the starch appears to dissolve slowly with time, destroying the effect observed here.

In the experiment shown in Fig. 1, tube $a$ was filled with 5 per cent bovine serum albumin and tube $b$ with 5 per cent stained bovine serum albumin in starch. After 5 hr. at 37,000 r.p.m., the rotor was decelerated without braking and the tubes gently removed. The distance the protein sedimented in free solution was measured by a method previously described ${ }^{2}$; the sedimentation distance in starch was estimated visually. Comparison of tubes $a$ and $b$ reveals that the protein moves through starch with a fairly well resolved trailing edge at about twice the rate observed in free solution. Tubes $c$ and $d$ contain uncentrifuged stained bovine serum albumin in starch and starch in buffer for comparison with tube $b$. No colour was observed in the upper fourth of tube $b$. Sectioning of the tube showed that the 